J. Proll

\title{
Small environmental temperature differences change energy utilization of growing rats
}

\section{Umgebungstemperatur und Energieverwertung}

\section{Introduction}

Food intake and body mass development of rats are influenced by room temperature. The aim of this study was to detect the influence on growth, body composition, and energy requirement of rats kept up to 6 weeks under small, permanent differences of temperature $\left(1-2{ }^{\circ} \mathrm{C}\right)$ in the animal room. Such differences may occur for example in ventilated but not fully air conditioned rooms between cages near and about $1.60 \mathrm{~m}$ above the floor.

\section{Materials and methods}

Rats, 5 weeks old, 18 animals/group, were kept in single cages $1.60 \mathrm{~m}$ (group 1) or $10 \mathrm{~cm}$ (group 2) above the floor for 6 weeks and fed with the standard feed Altromin 1320 ad libitum. The average difference of temperature in the cages amounted to $1.7^{\circ} \mathrm{C},\left(1^{\text {st }}-3^{\text {rd }}\right.$ week $)$ and $2.6{ }^{\circ} \mathrm{C}\left(4^{\text {th }}-6^{\text {th }}\right.$ week $)$ at $21 \pm 2{ }^{\circ} \mathrm{C}$ room temperature.

After 0,3 , and 6 weeks, 6 animals of each group were killed and carcass composition studied. Feed intake, growth, and body composition (energy, protein, fat) were determined. Energy and fat retention and energy utilization and requirements were calculated.

\section{Results}

The lower temperature in the cages (group 2) significantly caused a

- higher energy intake (ca. $20 \mathrm{~kJ} / \mathrm{kg}^{0.75}$ day ${ }^{\circ} \mathrm{C}$ )

- diminished growth (16 g within 6 weeks)

- reduced energy and fat content of the rats

- reduced energy and fat retention.

An increased requirement of energy for maintenance of $30 \mathrm{k} \mathrm{J} / \mathrm{kg}^{0.75}$ day per ${ }^{\circ} \mathrm{C}$ was observed. This is in agreement with results of similar but short-term measurements using indirect calorimetry.

\section{Conclusions}

These findings underline the necessity of a well balanced room and cage-temperature $\left(<1{ }^{\circ} \mathrm{C}\right.$ difference in all cages) for long term trials, when parameters of energy metabolism and growth are investigated. 